\title{
Clinical utility gene card for: Holoprosencephaly
}

\author{
Christèle Dubourg ${ }^{\star}, 1$, Véronique David ${ }^{1}$, Andrea Gropman ${ }^{2}$, Sandra Mercier ${ }^{1}$, Maximilian Muenke ${ }^{3}$, \\ Sylvie Odent ${ }^{1}$, Daniel E Pineda-Alvarez ${ }^{3}$ and Erich Roessler ${ }^{3}$
}

European Journal of Human Genetics (2010) 19, doi:10.1038/ejhg.2010.110; published online 21 July 2010

\section{DISEASE CHARACTERISTICS}

1.1 Name of the disease (synonyms)

Holoprosencephaly (HPE)

A mild subtype of HPE is called middle interhemispheric variant (MIHF) or syntelencephaly.

\subsection{OMIM\# of the disease \\ 236100 .}

1.3 Name of the analyzed genes or DNA/chromosome segments Major genes: SHH, $7 q 36$ (HPE3); ZIC2, 13q32 (HPE5); SIX3, 2p21 (HPE2); TGIF, 18p11.3 (HPE4).

Minor genes: GLI2, 2q14 (HPE9); PATCHED-1, 9q22 (HPE7); DISP1, 1q42; FOXH1, 8q24.3; NODAL, 10q22.1 and others.

\subsection{OMIM\# of the gene(s)}

SHH \#600725; ZIC2 \#603073; SIX3 \#603714; TGIF \#602630.

GLI2 \#165230; PATCHED-1 \#601309; DISP1 \#607502; FOXH1 \#603621; NODAL \#601265.

\subsection{Mutational spectrum}

The following percentages are referred to patients with non-chromosomic, non-syndromic HPE.

Point mutations and microrearrangements in the four main genes in $\sim 27 \%$ of isolated HPE cases ( $\mathrm{SHH} \sim 12 \%$, ZIC2 $\sim 9 \%$, SIX3 $\sim 5 \%$, TGIF $\sim 1 \%$ ).

Alterations in minor genes $<1 \%$. These minor genes with low mutation frequency rates are tested only in selected cases: for example, GLI2 is tested when specific abnormalities occur in the development of the pituitary gland, in the context of variable brain and craniofacial anomalies consistent with the broad spectrum of HPE.

\subsection{Analytical methods}

Search for point mutations:

D-HPLC (denaturing high-performance liquid chromatography) or HRM (high-resolution DNA melting) with confirmation by sequencing, or direct bi-directional sequencing.

Search for microrearrangements:

MLPA (multiplex ligation-dependent probe amplification) with SALSA Kit P187 Holoprosencephaly (MRC-Holland, Amsterdam, the Netherlands) or FISH (fluorescence in situ hybridization).

\subsection{Analytical validation}

Parallel analysis of positive and negative controls, depending on analytical method.

\subsection{Estimated frequency of the disease}

(Incidence at birth ('birth prevalence') or population prevalence): 1:10-16000 live births; 1:250 conceptuses.

1.9 If applicable, prevalence in the ethnic group of investigated person

Ethnic variations in birth prevalence rates could occur in HPE, but the available data are not convincing. Higher rates were generally observed among less favored minorities, probably because of a lower prenatal detection rate of HPE, and consequently less terminations of pregnancy. $^{2}$

\subsection{Diagnostic setting}

\begin{tabular}{lll}
\hline & Yes & No \\
\hline A. (Differential) diagnostics & $\Downarrow$ & $\square$ \\
B. Predictive testing & $\square$ & $\square$ \\
C. Risk assessment in relatives & $\Downarrow$ & $\square$ \\
D. Prenatal & $\Downarrow$ & $\square$ \\
\hline
\end{tabular}

Comment: Prenatal diagnosis is based primarily on fetal imaging, but 'molecular' prenatal diagnosis can be performed if a mutation or a microrearrangement has been previously identified in a proband. Interpretations of molecular diagnosis must be given with caution, given the lack of strict genotype-phenotype correlation, and should be offered in addition to fetal imaging, using ultrasound followed by fetal regional medical imaging.

\section{TEST CHARACTERISTICS}

\begin{tabular}{|c|c|c|c|c|}
\hline & \multicolumn{2}{|c|}{ Genotype or disease } & \multirow{2}{*}{$\begin{array}{l}\text { A: True positives } \\
\text { B: False positives }\end{array}$} & \multirow{2}{*}{$\begin{array}{l}\text { C: False negative } \\
\text { D: True negative }\end{array}$} \\
\hline & Present & Absent & & \\
\hline \multicolumn{5}{|l|}{ Test } \\
\hline Positive & $A$ & B & $\begin{array}{l}\text { Sensitivity: } \\
\text { Specificity: }\end{array}$ & $\begin{array}{l}A /(A+C) \\
D /(D+B)\end{array}$ \\
\hline Negative & C & $D$ & $\begin{array}{l}\text { Positive predictive value: } \\
\text { Negative predictive value: }\end{array}$ & $\begin{array}{l}A /(A+B) \\
D /(C+D)\end{array}$ \\
\hline
\end{tabular}

\footnotetext{
${ }^{1}$ Génétique Moléculaire, UMR 6061 CNRS IGDR, CHU Pontchaillou,University of Rennes, Rennes, France; ${ }^{2}$ CNMC Center for Neuroscience Research, Washington, DC, USA; ${ }^{3}$ National Human Genome Research Institute, National Institutes of Health, Bethesda, MD, USA

*Correspondence: Dr C Dubourg, Génétique Moléculaire, UMR 6061 CNRS, CHU Rennes, 2 rue Henri Le Guilloux, Rennes 35033, France.

Tel: +33 2992898 29; Fax: +332992892 48; E-mail: christele.dubourg@chu-rennes.fr
} 
2.1 Analytical sensitivity (proportion of positive tests if the genotype is present)

D-HPLC and HRM: > 95\% for heterozygous variants. Bi-directional sequencing: close to $100 \%$.

MLPA: not yet validated.

\subsection{Analytical specificity}

(proportion of negative tests if the genotype is not present)

D-HPLC and HRM:>95\% for heterozygous variants.

Bi-directional sequencing: close to $100 \%$.

MLPA: not yet validated.

\subsection{Clinical sensitivity}

(proportion of positive tests if the disease is present)

The clinical sensitivity can be dependent on variable factors such as age or family history. In such cases a general statement should be given, even if a quantification can only be performed case by case.

By testing the four main genes, mutations are identified in $\sim 27 \%$ of isolated HPE cases.

Mutations in SHH are identified in $\sim 12 \%$ of propositi $(10-30 \%$ de novo). The presence of structural brain anomalies in patients with SHH mutations is estimated to be $\sim 45 \%$, whereas the penetrance of any manifestations (including microform HPE) is estimated to be $\sim 90 \%$.

Mutations in ZIC2 are estimated to occur in up to $9 \%$ of propositi ( $72 \%$ de novo). Almost $90 \%$ of patients with mutations in ZIC2 have structural brain anomalies, and it is rare that a parent with a mutation will not show clear signs of cognitive impairment.

Mutations in SIX3 are estimated to occur in up to $5 \%$ of propositi (only $14 \%$ de novo). About $65 \%$ of patients with mutations in SIX3 have structural brain anomalies, most likely alobar rather than semilobar HPE.

Of the four genes commonly tested in clinical laboratories, mutations in TGIF are the least common, occurring in $\sim 1 \%$ of propositi. The role that alterations in TGIF have is not well understood.

Statistical analysis of combined results showed that propositi with structural brain anomalies who have either alobar or semilobar HPE are more likely to have a ZIC2 mutation, whereas SHH mutations seem to be responsible for most microform HPE. ${ }^{3}$

In a research context, further analysis include subtelomeres exploration using MLPA, and array comparative genome hybridization.

\subsection{Clinical specificity}

\section{(proportion of negative tests if the disease is not present)}

The clinical specificity can be dependent on variable factors such as age or family history. In such cases a general statement should be given, even if a quantification can only be performed case by case.

Close to $100 \%$ for SHH, ZIC2 and SIX3 alterations, if the biological meaning of variation has been ascertained by robust functional analyses.

The role of TGIF is less clear.
2.5 Positive clinical predictive value

(lifetime risk to develop the disease if the test is positive)

Non-chromosomal, non-syndromic HPE is classically considered an autosomal dominant condition with incomplete penetrance and highly variable expressivity. The spectrum of the effects of a single mutation within a single kindred is very wide.

Recent data point to a complex pattern of inheritance combining multiple interacting genetic and environmental factors. ${ }^{3}$ Therefore, because of this multihit hypothesis, not all carriers of a single deleterious mutation manifest clinically detectable symptoms. The identified mutation may be not sufficient to generate HPE, another event similar to an alteration in another gene (not yet identified) or an environmental factor being necessary.

\subsection{Negative clinical predictive value}

(probability not to develop the disease if the test is negative)

Assume an increased risk based on family history for a nonaffected person. Allelic and locus heterogeneity may need to be considered.

Index case in that family had been tested:

Close to $100 \%$ if the biological meaning of the identified family variation has been ascertained by robust functional analyses.

Index case in that family had not been tested:

Not resolved.

\section{CLINICAL UTILITY}

3.1 (Differential) diagnosis: the tested person is clinically affected (To be answered, if in 1.10 ' $\mathrm{A}$ ' was marked)

\subsubsection{Can a diagnosis be performed other than through a genetic test?}

\begin{tabular}{|c|c|c|}
\hline No & $\square$ (Continue with 3.1.4) & \\
\hline \multirow[t]{7}{*}{ Yes } & $\nabla$ & \\
\hline & Clinically & $\square$ \\
\hline & Imaging & $\nabla$ \\
\hline & Endoscopy & $\square$ \\
\hline & Biochemistry & $\square$ \\
\hline & Electrophysiology & $\square$ \\
\hline & Other (please describe) & \\
\hline
\end{tabular}

\subsubsection{Describe the burden of alternative diagnostic methods to the} patient

Brain magnetic resonance imaging (MRI) is essential for diagnosing HPE. Modern high-resolution MRI allows detailed analysis of the cortical, white matter and deep gray structural anomalies in HPE and leads to better classification of types of HPE. ${ }^{4}$

In prenatal, ultrasound can detect central nervous system and facail abnormalities of severe HPE as early as the first trimester, but is less sensitive for detection of milder forms of HPE, such as lobar HPE. Fetal MRI provide better characterization of brain malformations, but only later in the third trimester of pregnancy. ${ }^{5}$

3.1.3 How is the cost-effectiveness of alternative diagnostic methods to be judged?

Not applicable 
3.1.4 Will disease management be influenced by the result of a genetic test?

\begin{tabular}{|c|c|c|}
\hline No & \multicolumn{2}{|l|}{$\square$} \\
\hline \multirow[t]{4}{*}{ Yes } & $\otimes$ & \\
\hline & $\begin{array}{l}\text { Therapy } \\
\text { (please } \\
\text { describe) }\end{array}$ & $\begin{array}{l}\text { Depending on clinical symptoms: cerebrospinal fluid shunt } \\
\text { for treatment of hydrocephalus; antiepileptic medication; } \\
\text { physical therapy, bracing and orthopedic surgery for motor } \\
\text { impairment, anticholinergic drugs for dystonia; gastrostomy } \\
\text { for oromotor dysfunction; tracheostomy for treatment of upper } \\
\text { airway obstruction due to facial anomalies; } \mathrm{H} 2 \text { blockers or } \\
\text { proton-pump inhibitors for gastrointestinal problems; modifying } \\
\text { of the environment for hypothalamic dysfunction; hormones. }{ }^{6}\end{array}$ \\
\hline & $\begin{array}{l}\text { Prognosis } \\
\text { (please } \\
\text { describe) }\end{array}$ & $\begin{array}{l}\text { Higher mortality correlates with several factors, including } \\
\text { the severity of brain malformation, the severity of facial } \\
\text { malformation, the presence of a multiple congenital anomaly } \\
\text { syndrome, and the presence of chromosomal abnormalities. } \\
\text { Survival is associated with the severity of brain malformation } \\
\text { (short for alobar, intermediate for semilobar and the best for } \\
\text { lobar holoprosencephaly and mild forms). }{ }^{6}\end{array}$ \\
\hline & $\begin{array}{l}\text { Management } \\
\text { (please } \\
\text { describe) }\end{array}$ & $\begin{array}{l}\text { The results of genetic tests will influence genetic counseling } \\
\text { by permitting 'prenatal' diagnosis. }\end{array}$ \\
\hline
\end{tabular}

3.2 Predictive setting: the tested person is clinically unaffected but carries an increased risk based on family history

(To be answered, if in 1.10 'B' was marked)

\subsubsection{Will the result of a genetic test influence lifestyle and preven-} tion?

If the test result is positive (please describe):

If the test result is negative (please describe):

3.2.2 Which options in view of lifestyle and prevention does a person at-risk have if no genetic test has been performed (please describe)?

Not applicable

3.3 Genetic risk assessment in family members of a diseased person (To be answered, if in 1.10 ' $\mathrm{C}$ ' was marked)

3.3.1 Does the result of a genetic test resolve the genetic situation in that family?

No.

3.3.2 Can a genetic test in the index patient save genetic or other tests in family members?

No.
3.3.3 Does a positive genetic test result in the index patient enable a predictive test in a family member?

No.

\subsection{Prenatal diagnosis}

(To be answered, if in 1.10 'D' was marked)

3.4.1 Does a positive genetic test result in the index patient enable a prenatal diagnostic?

Yes, but 'molecular' prenatal diagnosis should be offered in addition to fetal imaging, which takes precedence for interpretation of the results.

\section{IF APPLICABLE, FURTHER CONSEQUENCES OF TESTING}

Please assume that the result of a genetic test has no immediate medical consequences. Is there any evidence that a genetic test is nevertheless useful for the patient or his/her relatives? (Please describe)

For the parents, the result conveys clarity about an eventual cause of the disease. In case of an identified alteration, heterozygote tests in relatives and prenatal diagnosis in pregnancies at risk can be offered as a consequence.

\section{CONFLICT OF INTEREST}

The authors declare no conflict of interest.

\section{ACKNOWLEDGEMENTS}

This work was supported by EuroGentest, an EU-FP6 supported NoE, contract number 512148 (EuroGentest Unit 3: 'Clinical genetics, community genetics and public health', Workpackage 3.2).

1 Pineda-Alvarez DE, Dubourg C, David V, Roessler E, Muenke M: Current recommendations for the molecular evaluation of newly diagnosed holoprosencephaly patients. Am J Med Genet C Sem Med Genet 2010; 154C: 93-101.

2 Orioli IM, Castilla EE: Epidemiology of holoprosencephaly: prevalence and risk factors. Am J Med Genet C Sem Med Genet 2010; 154C: 13-21.

3 Solomon BD, Mercier S, Vélez JI et al: Analysis of genotype-phenotype correlations in human holoprosencephaly. Am J Med Genet C Sem Med Genet 2010; 154C: 133-141.

4 Hahn JS, Barnes PD: Neuroimaging advances in holoprosencephaly: refining the spectrum of the midline malformation. Am J Med Genet C Sem Med Genet 2010; 154C: $120-132$.

5 Mercier S, Dubourg C, Belleguic M et al: Genetic counseling and 'molecular' prenatal diagnosis of holoprosencephaly (HPE). Am J Med Genet C Sem Med Genet 2010; 154C: 191-196.

6 Levey EB, Stashinko E, Clegg NJ, Delgado MR: Management of children with holoprosencephaly. Am J Med Genet C Sem Med Genet 2010; 154C: 183-190. 